\title{
PENGARUH INTERAKSI SOSIAL GURU DENGAN SISWA TERHADAP MOTIVASI BELAJAR DI JURUSAN TEKNIK GAMBAR BANGUNAN SMK NEGERI 1 CILAKU CIANJUR
}

\author{
Rieske Is wardhany ${ }^{1}$ dan Sri Rahayu ${ }^{2}$ \\ ${ }^{1,2}$ Pendidikan Teknik Bangunan, FPTK, UPI \\ Email: Rieske@upi.edu
}

\begin{abstract}
ABSTRAK
Interaksi sosial guru dengan sis wa sebagai faktor eksternal yang mampu mempeng aruhi motivasi belajar sis wa. Dalamproses belajar mengajar perlu sekali adanya interaksi guru dengan sis wa yang komunikatif,kondisi yang menyenangkan dan suas ana keakraban antara guru dan siswa. Sehingga deng an adanyarasasenangkepada guru. Maka, siswa dan siswi akan termotivasi untuk belajar. Penelitian ini bertujuan untuk 1) memperoleh gambaran Interaksi Sosial guru dengan siswa di Jurus an TGB SMK Negeri 1 Cilaku Cianjur; 2) Memperoleh gambaran Motivasi sis wa di Jurusan TGB SMK Negeri 1 Cilaku Cianjur; 3) Mengetahui seberapabesarPengaruh pengaruh Interaksi Sosial guru dengan siswa terhad ap motivasi belajar jurusan TGB SMK NegerilCilakuCianjur. Penelitian ini merupakan penelitan Deskriptif dengan menggunakan pendekatan kuantitatif. Instrumen pengumpulan data dengan menggunakan angket. Sampel penelitian dalampenelitian ini berjumlah $66 \mathrm{siswadari}$ jumlah populasi 66 siswa kelas XI program keahlian TGB SMK Negeri 1 Cilaku Cianjur. Dari hasil analis is data diperoleh hubung an y ang terjadi antara kedua variabel ters ebut positif dan signifikan. Gambaran interaksisosial sis wa dengan guru dalamkriteria baik. Sedangkan gambaran umumdari motivasi belajar siswa di jurus an TGB SMK Negeri 1 Cilaku Cianjur adalah tinggi. Berdasarkan pada kriteria penafsiran koefisien korelasi, hubungan antara kedua variabel tersebut termasuk dalam kategori kuat.
\end{abstract}

Kata kunci: Interaksi sosial, Motivasi, Belajar

\section{ABSTRACT}

Social interaction between student and teacher is a key factor to build student motivation. Enthusiasm member, good environment, familiarity is also needed in studying or learning process. Those points will be achieved maximal output result. This research pointing in 1) mechanism studying or learning processbetween members in majors TGB SMK Negeri 1 Cilaku Cianjur;2) motivation illustration in majors TGBSMKNegeri 1 Cilaku Cianjur; 3) Influence of social interaction between teacher and student relationship and alsostudent motivation in majors TGB SMK Negeri 1 Cilaku Cianjur. This research is descriptive using a quantitative approach. Data collection instrument using questionnaires, Sample of research total66studentpopulationclass of XITGB SMK Negri 1 Cilaku Cianjur. From the analysis of the data obtained a relationship between two variables is positive and significant, overview of social interaction of students and teachers in both criteria. General from student motivation in majors TGB SMK Negeri 1 Cilaku Cianjur is high. Based on thecriteriafor the interpretation of the correlation coefficient, the relationship between the two variablesincludedinthestrong category.

Keywords: Social interaction, Motivation, Learning

\section{PENDAHULUAN}

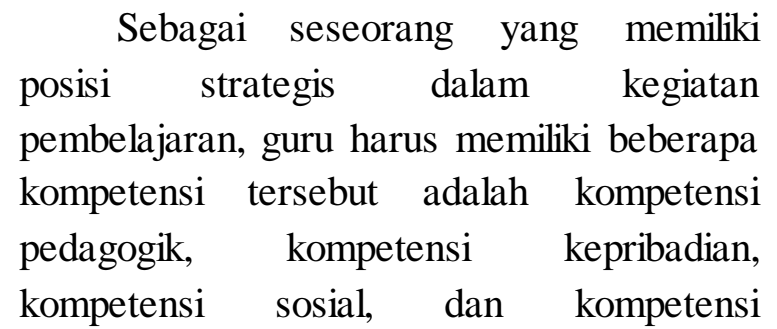

profesional. Berkaitan dengan kompetensi pedagogik yaitu kompetensi yang berhubungan langsung dengan keterampilan guru dalam kegiatan belajar mengajar. Dengan keterampilan guru dalam menciptakan iklim komunikatif diharapkan siswa dapat berpartisipasi aktif untuk mengeluarkan pendapatnya, 
mengembangkan imajinasinya dan daya kreativitasnya. Tentu komunikasi guru dan siswa yang dimaksud adalah dalam kegiatan pembelajaran tatap muka baik secara verbal maupun non verbal, baik secara individual maupun kelompok dan dibantu dengan media atau sumber belajar.

Di dalam interaksi sosial pembelajaran, tatap muka seorang guru mempunyai peran yang sangat penting di dalam kelas yaitu peran mengoptimalkan kegiatan belajar. Ada tiga kemampuan esensial yang harus dimiliki guru agar peran tersebut terealisasi, yaitu kemampuan merencanakan kegiatan, kemampuan melaksanakan kegiatan dan kemampuan mengadakan interaksi sosial. Ketiga kemampuan ini disebut generik essensial. Ketiga kemampuan ini sama pentingnya, karena setiap guru tidak hanya mampu merencanakan sesuai rancangan, tetapi harus terampil melaksanakan kegiatan belajar dan terampil menciptakan iklim yang komunikatif dalam kegiatan pembelajaran.

Iklim komunikatif yang baik dalam hubungan interpersonal antara guru dengan guru, guru dengan siswa, dan siswa dengan siswa merupakan kondisi yang memungkinkan berlangsungnya proses belajar mengajar yang efektif, karena setiap personal diberi kesempatan untuk ikut serta dalam kegiatan di dalam kelas sesuai dengan kemampuan masing-masing. Sehingga timbul situasi sosial dan emosional yang menyenangkan pada tiap personal, baik guru maupun siswa dalam melaksanakan tugas dan tanggung jawab masing-masing. Dalam menciptakan iklim komunikatif guru hendaknya memperlakukan siswa sebagai individu yang berbeda-beda, yang memerlukan pelayanan yang berbeda pula, karena siswa mempunyai karakteristik yang unik, memiliki kemampuan yang berbeda, minat yang berbeda, memerlukan kebebasan memilih yang sesuai dengan dirinya dan merupakan pribadi yang aktif. Untuk itulah kemampuan berinteraksi guru dalam kegiatan pembelajaran sangat diperlukan.

Kurangnya interaksi sosial antara guru dan siswa yang terjadi pada SMK Negeri 1 Cilaku Cianjur ini menggurangi motivasi siswa untuk belajar, hal ini disebabkan karena guru kurang terbuka dan luwes dalam pembelajaran, kurangnya kemampuan guru untuk mengelola interaksi siswa dalam kegiatan pembelajaran, menyebabkan siswa merasa sungkan untuk berinteraksi lebih dekat dengan guru. Dengan tidak terjadinya interaksi sosial yang baik antara guru dan siswa, siswa akan merasa kurangnya perhatian dari guru dan kurangnya motivasi belajar yang diberikan oleh guru kepada siswanya.

Mengingat banyak dan luas permasalahan yang dapat diteliti dalam penelitian ini, agar tidak menyebabkan masalah yang akan diteliti menjadi luas ruang lingkupnya serta terarah pada tujuan yang ingin dicapai. Maka dalam penelitian ini perlu adanya pembatasan masalah.

Pembatasan masalah yang akan diungkapkan oleh penulis adalah: 1) Siswa yang di teliti adalah siswa jurusan Teknik Gambar Bangunan kelas XI SMK NEGERI 1 Cilaku Cianjur. 2) Interaksi Sosial guru dengan siswa jurusan Teknik Gambar Bangunan di SMK NEGERI 1 Cilaku Cianjur. 3) Motivasi belajar siswa SMK Negeri 1 Cilaku Cianjur.

Rumusan masalah pada penelitian ini adalah: 1) Bagaimana gambaran interaksi sosial guru dengan siswa jurusan Teknik Gambar Bangunan SMK NEGERI 1 Cilaku Cianjur ? 2) Bagaimana gambaran motivasi belajar siswa jurusan Teknik Gambar Bangunan SMK NEGERI 1 Cilaku Cianjur 


\section{Pengaruh Interaksi Sosial ... (Rieske/ hal. 78-88)}

? 3) Seberapa besar pengaruh interaksi sosial guru dengan siswa terhadap motivasi belajar siswa SMK NEGERI 1 Cilaku ?

Tujuan dari penelitian ini adalah: 1) Untuk mengetahui interaksi sosial guru dengan siswa jurusan Teknik Gambar Bangunan SMK Negeri 1 Cilaku Cianjur. 2) Untuk mengetahui motivasi belajar siswa jurusan Teknik Gambar Bangunan SMK Negeri 1 Cilaku Cianjur. 3) Untuk mengetahui besarnya pengaruh Interaksi Sosial guru dengan siswa terhadap motivasi belajar siswa jurusan Teknik Gambar Bangunan SMK Negeri 1 Cilaku Cianjur.

\section{METODE}

Penelitian ini menggunakan metode deskriptif. Menurut M.Nasir (1999:64) "Metode penelitian deskriptif adalah pencarian fakta dengan interpretasi yang tepat. Penelitian deskriptif mempelajari masalah-masalah dalam masyarakat serta tata cara yang berlaku dalam masyarakat akan situasi-situasi tertentu termasuk tentang hubungan, kegiatan-kegiatan, sikapsikap, pandangan-pandangan, serta proses yang sedang berlangsung dan pengaruhpengaruh dari suatu fenomena". Pendekatan yang digunakan dalam penelitian ini menggunakan pendekatan kuantitatif, yaitu pendekatan yang memungkinkan dilakukan pencatatan data hasil penelitian secara nyata dalam bentuk angka sehingga memudahkan proses analisis data dan penafsirannya.

Berdasarkan penjelasan diatas, maka metode yang digunakan dalam penelitian ini adalah metode deskriptif dengan pendekatan kualitatif, yaitu hasil penelitian yang kemudian diolah dan dianalisis untuk diambil kesimpulannya, artinya penelitian yang dilakukan adalah penelitian yang menekankan analisisnya pada data-data numeric (angka), dengan menggunakan metode penelitian ini akan diketahui hubungan yang signifikan antara variabel yang diteliti, sehingga menghasilkan kesimpulan yang akan memperjelas gambaran mengenai objek yang diteliti.

\section{Metode Pengumpulan Data}

Pengumpulan data merupakan sebuah prosedur untuk memperoleh data dalam usaha memecahkan permasalahan dengan menggunakan alat-alat yang digunakan oleh peneliti.

Adapun teknik pengumpulan data dalam penelitian ini menggunakan teknik Angket. Angket adalah sejumlah pertanyaan yang ditulis yang digunakan untuk memperoleh informasi dari responden dalam arti laporan tentang pribadinya, atau hal-hal yang ia ketahui (Arikunto, 2010:150).

Angket dibuat berdasarkan kisi-kisi instrument penelitian yang telah ditentukan. Angket ini merupakan angket tertutup, dimana responden hanya memilih salah satu alternatif jawaban yang dianggap paling sesuai dengan pendapatnya.

\section{Metode Analis is Data}

Analisis data adalah proses mencari dan menyusun secara sistematis data yang diperoleh dari hasil uji coba instrument yang di ujicobakan. Dengan cara mengorganisasikan data ke dalam kategori, menjabarkan ke dalam unit-unit, melakukan sintesa, menyusun ke dalam pola, memilih mana yang penting dan yang akan dipelajari, dan membuat kesimpulan sehingga mudah dipahami oleh diri sendiri maupun orang lain. (Sugiyono. 2012 : 335).

Langkah-langkah yang dilakukan peneliti dalam memproses data, adalah sebagai berikut. 


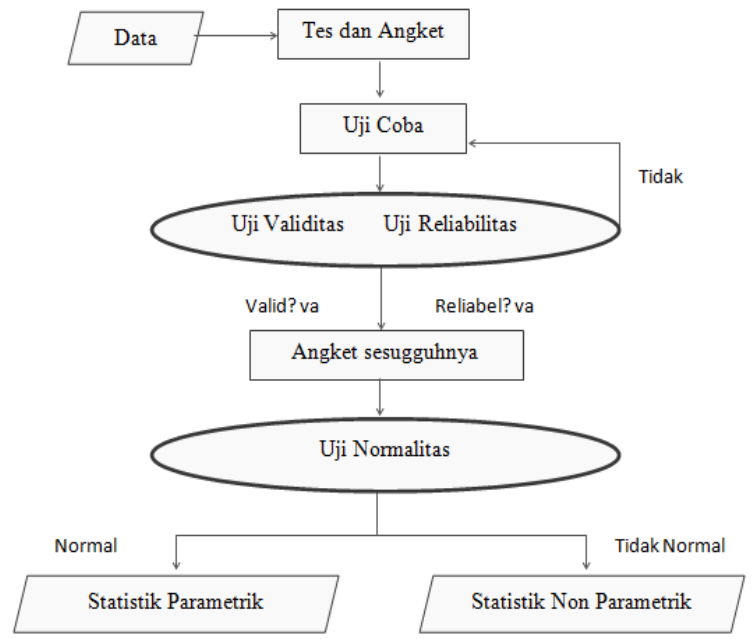

Sumber: DR. Rina Marina, MP

Gambar 1. Bagan Analisis Data

Dalam analisis data ini, hal pengolahan data diperlukan untuk membuktikan kebenaran hipotesis yang telah dirumuskan apakah hipotesis yang telah dirumuskan apakah hipotesis tersebut diterima atau ditolak. Pengolahan data hasil penyebaran angket meliputi perhitungan konversi T-Skor, Perhitungan Uji Kecenderungan, Deskripsi Variabel, Uji Normalitas, Analisa Korelasi, Uji Hipotesis dan Koefisien Determinasi.

\section{HASIL DAN PEMBAHASAN}

\section{Deskripsi Variabel Per Indikator \\ Deskripsi Variabel X}

Data penelitian ini diperoleh dari responden yaitu siswa SMK Negeri 1 Cilaku Cianjur kelas XI Jurusan Teknik Gambar Bangunan yang berjumlah 66 responden dari total populasi 66 responden. Alat pengumpul data yang digunakan untuk variabel $\mathrm{X}$ adalah angket.

Sebanyak 32 item untuk angket variabel $\mathrm{X}$ yang sebelumnya telah diuji cobakan diluar sampel yang digunakan dan dinyatakan valid dan reliabel diujikan kepada 66 responden yang termasuk dalam populasi penelitian.

DIAGRAM BATANG GAMBARAN PER INDIKATOR DAN ASPEK VARIABEL $X$

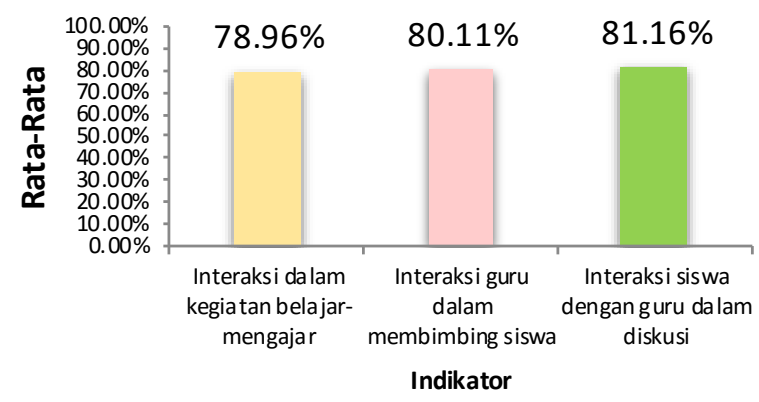

Gambar 2. Diagram Batang Deskripsi Variabel X

Berdasarkan diagram batang diatas terdiri dari tiga indikator pada aspek variabel $\mathrm{X}$ diantaranya adalah Interaksi dalam kegiatan belajar-mengajar presentase sebesar 78,96\%, Interaksi guru dalam membimbing siswa sebesar $80,11 \%$ dan Interaksi siswa dengan guru dalam diskusi $81,16 \%$.

Jadi indikator terendah adalah Interaksi dalam kegiatan belajar-mengajar presentase sebesar $78,96 \%$ dan indikator tertinggi adalah Interaksi siswa dengan guru dalam diskusi $81,16 \%$. Secara keseluruhan gambaran indikator keseluruhan dari aspek variabel $\mathrm{X}$ memiliki presentase $80,1 \%$ yang termasuk ke dalam kriteria tinggi.

\section{Deskripsi Variabel Y}

Data penelitian ini diperoleh dari responden yaitu siswa SMK Negeri 1 Cilaku Cianjur kelas XI Jurusan Teknik Gambar Bangunan yang mengikuti mata pelajaran kompetensi kejuruan semester satu yang berjumlah 66 responden dari total populasi 66 responden. Alat pengumpul data yang digunakan untuk variabel $\mathrm{Y}$ adalah angket.

Sebanyak 33 item untuk angket variabel $\mathrm{Y}$ yang sebelumnya telah diuji cobakan diluar sampel yang digunakan dan dinyatakan valid dan reliabel diujikan 
kepada 66 responden yang termasuk dalam populasi penelitian.

Persentase dari tiap indikator dan aspek yang diungkap dari variabel $\mathrm{Y}$ yaitu interaksi sosial siswa dengan guru.

DIAGRAM BATANG GAMBARAN PER INDIKATOR DAN ASPEK VARIABELY

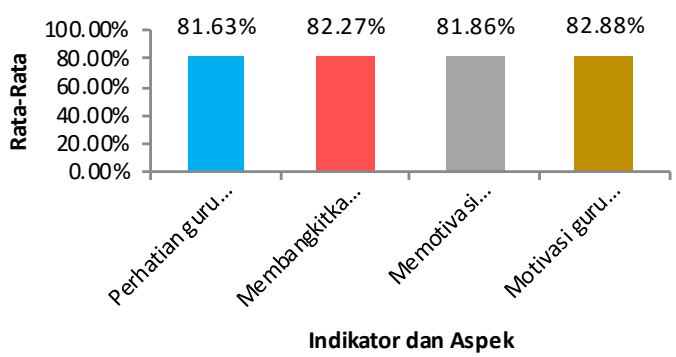

Gambar 3. Diagram Batang Deskripsi Variabel Y

Berdasarkan diagram batang diatas terdiri dari tiga indikator pada aspek variabel $\mathrm{X}$ diantaranya adalah Perhatian guru kepada siswa presentase sebesar 81,63\%, membangkitkan motivasi kepada anak didik untuk belajar presentase sebesar 82,27\%, memotivasi siswa dengan metode yang bervariasi persentase sebesar $81,86 \%$ dan motivasi guru untuk membantu kesulitan belajar siswa presentase sebesar $82,88 \%$.

Jadi indikator terendah adalah indikator Perhatian guru kepada siswa presentase sebesar $81,63 \%$, dan indikator tertinggi adalah indikator motivasi guru untuk membantu kesulitan belajar siswa presentase sebesar 82,88\%. Secara keseluruhan gambaran indikator keseluruhan dari aspek variabel Y memiliki presentase $80,19 \%$ yang termasuk ke dalam kriteria tinggi

\section{Analis is Data Penelitian}

\section{Uji Normalitas}

Uji normalitas digunakan untuk mengetahui apakah data yang terkumpul berdistribusi normal atau tidak. Pengujian ini menentukan penggunaan rumus statistik yang digunakan pada analisis selanjutnya. Apabila data berdistribusi normal maka perhitungan selanjutnya menggunakan statistik parametrik dan dapat menggunakan rumus product moment correlation dari Pearson dan jika data tidak berdistribusi normal maka digunakan statistik non parametrik dapat digunakan rumus rank spearman.

\section{Hasil Uji Normalitas Variabel $\mathbf{X}$}

Untuk mengetahui kenormalan data variabel $\mathrm{X}$, uji normalitas dilakukan dengan menggunakan rumus Chi-Kuadrat dan diperoleh harga Chi-Kuadrat $\left(\chi^{2}\right)=7,720$. Nilai Chi-Kuadrat $\left(\chi^{2}\right)$ yang diperoleh kemudian dikonsultasikan pada tabel distribusi $\chi^{2}$ dengan $\mathrm{dk}=\mathrm{k}-1=7-1=6$. Tingkat kepercayaan $95 \%$ dan setelah dikonsultasikan pada tabel $\chi^{2}$ diperoleh $\chi^{2}$ $(95 \%)(6)=12,592$.

Jika $\chi^{2}$ hitung $>\chi^{2}$ tabel, artinya distribusi data tidak normal.

Jika $\chi^{2}$ hitung $<\chi^{2}$ tabel, artinya distribusi data normal.

Ternyata nilai $\chi^{2}$ hitung $(7,720)<\chi^{2}$ tabel (12,592). Maka dapat disimpulkan bahwa distribusi data variabel (X) interaksi sosial siswa dengan guru tersebut berdistribusi normal pada tingkat kepercayaan $95 \%$.

\section{Hasil Uji Normalitas Variable Y}

Untuk mengetahui kenormalan data variabel Y, uji normalitas dilakukan dengan menggunakan rumus Chi-Kuadrat dan diperoleh harga Chi-Kuadrat $\left(\chi^{2}\right)=2,903$. Nilai Chi-Kuadrat $\left(\chi^{2}\right)$ yang diperoleh kemudian dikonsultasikan pada tabel distribusi $\chi^{2}$ dengan $\mathrm{dk}=\mathrm{k}-1=7-1=6$. Tingkat kepercayaan $95 \%$ dan setelah dikonsultasikan pada tabel $\chi^{2}$ diperoleh $\chi^{2}$ $(95 \%)(6)=12,592$. Ternyata nilai $\chi^{2}$ hitung $(2,903)<\chi^{2}$ tabel $(12,592)$. Maka dapat 
disimpulkan bahwa distribusi data variabel (Y) motivasi belajar siswa tersebut berdistribusi normal pada tingkat kepercayaan $95 \%$.

Berdasarkan hasil uji normalitas menunjukkan bahwa data variabel $\mathrm{X}$ dan variabel $\mathrm{Y}$ berdistribusi normal, maka dalam penelitian ini selanjutnya akan menggunakan analisis statistik parametrik.

\section{Uji Homogenitas}

Uji homogenitas pada prinsipnya ingin menguji apakah sebuah populasi (data kategori) mempunyai varians yang sama di antara populasi tersebut. Jika varians sama maka dikatakan homogen dan sebaliknya jika varians tidak sama dikatakan tidak homogen. Uji homogenitas untuk persyaratan analisis regresi menggunakan teknik yang sama dengan uji homogenitas untuk persyaratan uji perbedaan. Dasar pengambilan keputusan Jika $F_{\text {hitung }} \geq F_{\text {tabel }}$ berarti Distribusi data tidak homogen, sebaliknya Jika $F_{\text {hitung }} \leq \mathrm{F}_{\text {tabel }}$ berarti Data Distribusi Homogen.

Hasil perhitungan uji homogenitas didapat Fhitung sebesar 1,577 dan $F_{\text {tabel }}$ sebesar 1,858 sehingga dapat terlihat bahwa $F_{\text {hitung }} \leq \mathrm{F}_{\text {tabel }}$ hal ini berarti data dinyatakan homogen.

\section{Uji Korelasi Product Momen}

Dalam penelitian ini pada variabel $\mathrm{X}$ dan variabel $\mathrm{Y}$ berdistribusi normal, maka perhitungan analisis korelasi menggunakan rumus Pearson Product Moment

Hasil Perhitungan Korelasi dengan menggunakan rumus Pearson Product Moment memperoleh harga $r$ sebesar 0,610, dimana harga $r$ sebesar 0,610 berada pada rentang $0,600-0,799$. Maka dapat disimpulkan bahwa koefisien korelasi penelitian ini termasuk dalam tingkat korelasi kuat, dengan demikian dapat diartikan bahwa interaksi sosial siswa dengan guru mempunyai hubungan yang kuat dengan motivasi belajar siswa di jurusan teknik gambar bangunan SMK Negeri 1 Cilaku Cianjur.

\section{Analisis Regresi Sederhana}

Perhitungan regresi didasarkan pada hubungan fungsional ataupun kausal satu variabel independen dengan satu variabel dependen. Untuk mencari persamaan regresi terlebih dahulu mencari nilai koefisien a dan b. Hasil perhitungan regresi dari variabel $X$ yaitu interaksi sosial siswa dengan guru dan variabel $\mathrm{Y}$ yaitu motivasi belajar siswa sebagai berikut :

$$
\widehat{\boldsymbol{Y}}=\boldsymbol{a}+\boldsymbol{b x}=60,14+0,444 \mathrm{x}
$$

Dari hasil perhitungan didapatkan nilai $\mathrm{F}_{\text {hitung }}=1,876$. Harga $\mathrm{F}_{\text {hitung }}$ ini dikonsultasikan kedalam $F_{\text {tabel }}$ dan diperoleh $F_{(0,95)(25,39)}=1,891$. Ternyata harga $F_{\text {hitung }}$ dari perhitungan lebih kecil dari harga Ftabel $\left(\mathrm{F}_{\text {hitung }}=1,876 \leq \mathrm{F}_{\text {tabel }}=1,891\right)$ maka persamaan regesi berpola linier.

Sedangkan untuk mengetahui keberartian regresi dapat dilihat dari $\mathrm{F}_{\text {hitung }}=$ 23,777 yang kemudian dibandingkan dengan $F_{\text {tabel }}$ yaitu $F_{(0,95)(1,64)}=3,991$. Ternyata $F_{\text {hitung }}$ $>$ dari $F_{\text {tabel }}$ maka dapat disimpulkan bahwa arah regresi positif dan signifikan pada taraf kepercayaan $95 \%$, dengan derajat kebebasan (dk) pembilang 1 dan penyebut 64. Maka dapat disimpulkan Ho di tolak sedangkan $\mathrm{Ha}$ diterima, yang berarti interaksi sosial siswa dengan guru berpengaruh terhadap motivasi belajar siswa.

Pengujian hipotesis dalam penelitian ini menggunakan rumus uji t. Dari hasil perhitungan didapatkan harga $\mathrm{t}=6,163$. Hasil perhitungan dikonsultasikan dengan harga $t_{\text {tabel }}$. Maka, diperoleh $t_{\text {tabel }}=1,998$ dengan taraf kepercayaan $90 \%$ dan $\mathrm{dk}=\mathrm{n}$ $2=66-2=64$. 
Besarnya konstribusi variabel $\mathrm{X}$ terhadap variabel $\mathrm{Y}$ dihitung dengan rumus Koefisien Diterminasi (KD), yaitu :

$\mathrm{r}=\mathbf{0 , 6 1 0}$

KD $=r^{2} \times 100 \%=0,610^{2} \times 100 \%=$ $37,21 \%$

Koefisien determinasi variabel $\mathrm{X}$ (interaksi sosial siswa dengan guru) terhadap variabel Y (motivasi belajar siswa) didapat sebesar $39,041 \%$ dan sisanya $60,959 \%$ motivasi belajar siswa dipengaruhi oleh faktor lain yaitu kemampuan siswa, cita-cita siswa, kondisi siswa, lingkungan tempat tinggal, dan guru.

\section{Uji Hipotesis}

Pengujian hipotesis dilakukan untuk menerima atau menolak hipotesis yang diajukan dalam penelitian ini. Terdapat dua macam hipotesis penelitian yang akan diuji yaitu hipotesis kerja dan hipotesis nol. Hipotesis kerja dengan simbol $\mathrm{Ha}$ yang dinyatakan dengan kalimat positif dan untuk hipotesis nol dengan simbol Ho yang dinyatakan dengan kalimat negatif.

Hipotesis yang akan diuji adalah :

$\mathrm{Ha}: \beta>0$ "Terdapat pengaruh yang positif dan signifikan dari interaksi sosial siswa dengan guru terhadap motivasi belajar di Jurusan Teknik Gambar Bangunan SMK Negeri 1 Cilaku Cianjur"

Ho: $\beta=0$ "Tidak terdapat pengaruh yang positif dan signifikan dari interaksi sosial siswa dengan guru terhadap motivasi belajar di Jurusan Teknik Gambar Bangunan SMK Negeri 1 Cilaku Cianjur".

Selanjutnya dapat dilakukan pengujian hipotesis penelitian yaitu:

Jika $t_{\text {hitung }}>t_{\text {tabel }}$, maka Ho ditolak dan Ha diterima.
Jika $t_{\text {hitung }}<t_{\text {tabel }}$, maka Ho diterima dan Ha ditolak.

Berdasarkan hasil perhitungan $t_{\text {hitung }}=$ 6,163. Selanjutnya harga thitung dikonsultasikan dengan ttabel dengan taraf kepercayaan 95\% dan $\mathrm{dk}=\mathrm{n}-2=66-2=64$, diperoleh $\mathrm{t}_{(0,95)} \quad(1,64)=1,998$. Dengan demikian dapat diketahui bahwa $t_{\text {hitung }}$ $(6,163)>t_{\text {tabel }}(1,998)$ maka Ho ditolak dan Ha diterima yang artinya signifikan. Dapat diartikan bahwa terdapat pengaruh yang positif dan signifikan dari interaksi sosial siswa dengan guru terhadap motivasi belajar di Jurusan Teknik Gambar Bangunan SMK Negeri 1 Cilaku Cianjur.

Pengaruh Variabel X (Interaksi Sosial Guru dengan Siswa) terhadap Variabel Y (Motivasi Belajar Sis wa)

Pengaruh yang dimaksud adalah hubungan yang terjadi antar variabel yang kemudian dikonsultasikan dengan kriteria penafsiran. Sebelum membahas pengaruh interaksi sosial guru dengan siswa terhadap motivasi belajar siswa di SMK Negeri 1 Cilaku Cianjur. Terlebih dahulu hubungan kedua variabel tersebut harus diketahui untuk menentukan perlu tidaknya pengaruh kedua variabel dihitung dan ditafsirkan. Pengaruh interaksi sosial guru dengan siswa terhadap motivasi belajar siswa SMK Negeri 1 Cilaku Cianjur dihitung dengan menggunakan korelasi product moment dari Pearson.

Koefisien korelasi untuk variabel $\mathrm{X}$ terhadap Y sebesar 0,610 berada pada interval 0,600 - 0,799 termasuk kategori kuat dan signifikan dengan demikian dapat diartikan bahwa interaksi sosial guru dengan siswa memilki pengaruh terhadap motivasi belajar siswa. Sesuai dengan hasil penelitian, motivasi belajar siswa tidak dapat berdiri sendiri tetapi mendapat pengaruh dari interaksi sosial guru dengan siswa. Pengaruh 
dari interaksi sosial guru dengan siswa terhadap motivasi belajar siswa adalah sebesar 37,16\%, dan sisanya $62,84 \%$ dipengaruhi oleh faktor lainnya yaitu kemampuan siswa, cita-cita siswa, kondisi siswa, lingkungan tempat tinggal, dan guru yang didapat dari perhitungan koefisien diterminasi.

Perhitungan pada distribusi $\mathrm{t}$ yang telah dibahas, disimpulkan bahwa interaksi sosial guru dengan siswa terhadap motivasi belajar siswa memiliki nilai korelasi yang signifikan dan dapat digenerlisasikan, sehingga hipotesis Ha diterima Ho ditolak, Maka dapat diartikan terdapat hubungan interaksi sosial guru dengan siswa terhadap motivasi belajar siswa besarnya nilai hubungan tersebut sebesar 0,610. Sifat korelasi kuat menunjukkan semakin tinggi interaksi sosial guru dengan siswa maka semakin tinggi motivasi belajar siswa, sebaliknya semakin rendah interaksi sosial guru dengan siswa maka semakin rendah motivasi belajar siswa

Berdasarkan landasan teori bahwa interaksi antara guru dengan siswa dalam melakukan proses komunikasi yang harmonis sehingga tercapai suatu hasil yang diinginkan dapat dilakukan contact-hours atau jam-jam bertemu antara guru dan siswa, dimana guru dapat menanyai dan mengungkapkan keadaan siswa dan sebaliknya siswa mengajukan persoalanpersoalan dan hambatan-hambatan yang dihadapinya.

Banyak faktor yang ada diluar diri individu yang mempengaruhi motivasi, usaha dan keberhasilan belajarnya. Salah satunya yaitu aspek Interaksi sosial guru dengan siswa di sekolah. Salah satu faktor yang mempengaruhi kualitas pembelajaran adalah variabel guru. Guru mempunyai pengaruh yang cukup dominan terhadap kualitas pembelajaran, karena gurulah yang bertanggung jawab terhadap proses pembelajaran di kelas, bahkan sebagai penyelenggara pendidikan di sekolah.

Dalam proses belajar mengajar perlu sekali adanya kondisi yang menyenangkan dan suasana keakraban antara guru dan siswa. Sehingga dengan adanya rasa senang kepada guru. Maka, siswa lebih sungguhsungguh dalam belajar. Sebaliknya siswa yang tidak senang dengan guru akan cenderung menurun motivasi belajaranya. Dengan menjalin keakraban dengan siswa dalam proses belajar mengajar, perlu dikembangkan, karena proses akrab guru dengan siswa atau sebaliknya akan memudahkan guru dalam membimbing dan mengarahkan siswa dalam meraih hasil dalam membentuk sikap dan pribadinya.

Dengan demikian dapat dikatakan bahwa proses belajar mengajar akan dapat berlangsung dengan baik apabila adanya hubungan baik antara guru dengan siswa, dan hal ini bisa terjadi kalau guru telah dapat berinteraksi dengan siswa-siswanya disekolah maupun diluar sekolah. Dapat disimpulkan bahwa,

Terdapat pengaruh yang positif dan signifikan antara interaksi sosial guru dengan siswa terhadap motivasi belajar di Jurusan Teknik Gambar Bangunan SMK Negeri 1 Cilaku Cianjur.

Berdasarkan penelitian yang telah dilakukan diperoleh hasil bahwa interaksi guru dengan siswa berpengaruh terhadap motivasi belajar di Jurusan Teknik Gambar Bangunan SMK Negeri 1 Cilaku Cianjur dan pengaruhnya bersifat positif (nilai koefisien regresinya sebesar 0,522), artinya jika interaksi guru dengan siswa semakin baik maka akan meningkatkan motivasi belajar siswa. Berdasarkan nilai regresi tersebut dapat diketahui bahwa jika interaksi sosial 
guru dengan siswa meningkat sebesar $10 \%$ maka motivasi belajar siswa akan meningkat $5,2 \%$. Sedangkan berdasarkan nilai koefisien korelasi dan koefisien determinasi diketahui bahwa variabel independen (Interaksi sosial guru dengan siswa) mempunyai hubungan yang kuat dan mempunyai sumbangan yang cukup besar terhadap variabel dependen (motivasi belajar siswa).

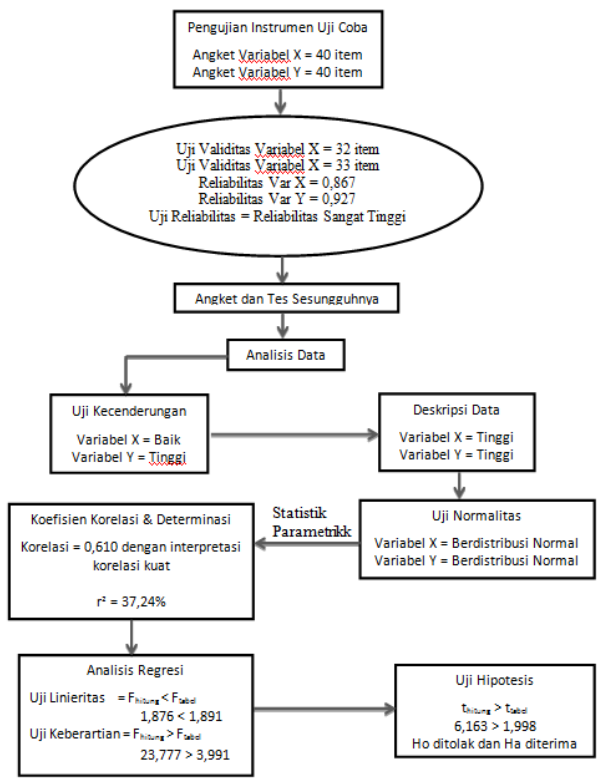

Gambar 4. Resume Perhitungan Hipotesis

\section{KESIMPULAN}

Kesimpulan pada dasarnya merupakan jawaban dari masalah penelitian ini yang dikemukakan. Berdasarkan rumusan masalah, tujuan penelitian, pengujian hipotesis dan hasil penelitian, pengaruh Interaksi siswa dengan guru terhadap motivasi belajar siswa, yang telah dilakukan, dapat diambil kesimpulan sebagai berikut, yaitu 1) Gambaran umum interaksi siswa dengan guru di SMK Negeri 1 Cilaku Cianjur dilihat dari indikator interaksi dalam kegiatan belajar-mengajar, interaksi guru dalam membimbing siswa, dan interaksi siswa dengan guru dalam diskusi termasuk pada kriteria baik dengan persentase sebesar $34,85 \%$ dari 23 responden dengan populasi 66 responden; 2) Gambaran umum dari motivasi belajar siswa program keahlian teknik gambar bangunan SMK Negeri 1 Cilaku Cianjur dilihat dari indikator motivasi belajar siswa yang diteliti adalah Perhatian guru kepada siswa, Membangkitkan motivasi kepada siswa untuk belajar, memotivasi belajar siswa dengan metode yang bervariasi, dan Motivasi guru untuk membantu kesulitan belajar siswa. Indikator-indikator pengukur motivasi belajar siswa termasuk pada kriteria tinggi dengan persentase sebesar $37,87 \%$ dari 25 responden dengan populasi 66 responden; dan 3) Berdasarkan penelitian yang telah dilakukan diperoleh hasil bahwa interaksi guru dengan siswa berpengaruh terhadap motivasi belajar di Jurusan Teknik Gambar Bangunan SMK Negeri 1 Cilaku Cianjur dan pengaruhnya bersifat positif (nilai koefisien regresinya sebesar 0,522), artinya jika interaksi guru dengan siswa semakin baik maka akan meningkatkan motivasi belajar siswa.

\section{SARAN}

Dalam penelitian pendidikan ini, penulis ingin penulis ingin mengemukaan beberapa saran. Adapun saran yang diajukan penulis adalah sebagai berikut, yaitu 1) Bagi siswa, diharapkan agar dapat berinteraksi lebih baik lagi dengan guru. Siswa diharapkan jangan ragu untuk mengungkapkan pendapat dan bertanya kepada guru. Hal tersebut bertujuan untuk membangun interaksi belajar mengajar guru dan siswa yang baik diharapkan dapat meningkatkan hasil belajar siswa; 2) Bagi guru, diharapkan dapat memberikan motivasi agar merangsang siswa siswa untuk berperan aktif dalam 
setiap mata pelajaran sehingga terjalin dengan baik, dengan demikian diharapkan siswa mampu memperoleh hasil belajar yang baik; dan 3) Bagi pembaca, mudah-mudahan karya tulis ini dapat dijadikan bahan acuan untuk penelitian lebih lanjut. Bagi penulis lain yang ingin melanjutkan sebaiknya cari faktor-faktor lain yang mempengaruhi motivasi belajar siswa.

\section{DAFTAR RUJUKAN}

Ali, Muhammad. (2004). Psikologi Remaja Perkembangan Peserta Didik. Bandung : Bumi Aksara.

A.M. Sardiman. (2012). Interaksi dan Motivasi Belajar Mengajar. Jakarta: Rajawali.

Arikunto, Suharsimi. (2009). Prosedur penelitian suatu pendekatan praktik. Jakarta: Rineka Cipta.

Dimyati. Dan Mudjiono. (2006). Belajar dan Pembelajaran. Jakarta: Rineka Cipta.

Joni, T. Raka. (1984). Pedoman Umum Alat Penilaian Kemampuan Guru. Jakarta: Dirjen Pendidikan Tinggi Depdikbud.

Lunenburg, Fred C. (2011) Expectancy Theory of Motivation: Motivating by Altering Expectations. [ONLINE]

Tersedia:https://www.google.com/ur 1 ? sa $=\mathrm{t} \& \mathrm{rct}=\mathrm{j} \& \mathrm{q}=\& \mathrm{esrc}=\mathrm{s} \&$ source $=$ web\&cd $=1 \&$ cad $=$ rja $\&$ ved $=0 \mathrm{CCsQF}$ jAA\&url=http\%3A\%2F\%2Fwww.n ationalforum.com $\% 2$ FElectronic $\% 2$ 520Journal $\% 2520$ Volumes $\% 2$ FLun eneburg\%2C\%2520Fred $\% 2520 \mathrm{C} \% 2$ 520Expectancy $\% 2520$ Theory $\% 2520$ $\% 2520$ Altering $\% 2520$ Expectations
\%2520IJMBA\%2520V15\%2520N1 $\%$ 25202011.pdf\&ei=eybWUaCsGsa PrQfB1YDABg\&usg=AFQjCNFIO te7BFwdWKd7U35aDd6oAdt9iA\& sig2=Vf9g8qpzKsviqb4w1DfkZg\& bvm=bv.48705608,d.bmk

Maryati dan Suryawati. (2005). Sosiologi. Esis, Jakarta

Muhibbin. (2006). Psikolog Pendidikan dengan Pendekatan Baru. Bandung: PT. Remaja Rosdakarya.

Murdiyatmoko dan Handayani. (2004). Pengertian Interaksi Sosial. [ONLINE] Tersedia : http:/jurnalsdm.blogspot.com/2009/05/interaksi -sosial-definisi-bentuk-ciri.html [20Oktober2012]

Nazir, M. (1999). Metode Penelitian. Jakarta: Ghalia Indonesia.

Nana, Sudjana. (2002). Dasar-Dasar Proses Belajar Mengajar. Bandung: Sinar Baru Algensindo.

Nelson, Lindsey D. (1998). Herbert Blumer's Symbolic Interactionism. [ONLINE]

Tersedia:

http://www.colorado.edu/communic ation/metadiscourses/Papers/App_Papers/Nels on.htm

Prasetya, Darman. (2010). Interaksi Guru dan Siswa. [ONLINE] Tersedia: http://smkfarmasiyansal.blogspot.co $\mathrm{m} / 2010 / 04 /$ interaksi-guru-dansiswa.html [20 Oktober2012] 
Pengaruh Interaksi Sosial ... (Rieske/ hal. 78-88)

Rainey. (1965) Motivasi Intrinsik \& Ekstrinsik [ONLINE]

Tersedia http://11031melinas.blogspot.com/2 012/04/motivasi-intrinsikekstrinsik.html [20Oktober2012]

Riduwan. (2009). Belajar Mudah Penelitian untuk Guru-Karyawan dan Peneliti Pemula. (Edisi Keenam). Bandung : Alfabeta.

Ripandelli, April M. Contextual Teaching and Learning. [ONLINE]

Tersedia:https://www.google.com/ur 1 ? $\mathrm{sa}=\mathrm{t} \& \mathrm{rct}=\mathrm{j} \& \mathrm{q}=\& \mathrm{esrc}=\mathrm{s} \&$ source $=$ web\&cd $=3 \& \mathrm{cad}=\mathrm{rja} \& \mathrm{ved}=0 \mathrm{CEYQ}$ FjAC\&url=http\%3A\%2F\%2Fwww. kennesaw.edu\%2Fenglish\%2FConte xtualLearning\% 2F2003\%2FBartow \%2FAprilRipandelli.pdf\&ei=MyrW UceVE4TIrQe3IGADQ\&usg=AFQjCNGJM80Rlr nmWRphdlz0kNTlyrm6cw\&sig2= V2VaqPgWCakjS0w4efKdQ\&bvm=bv.4870 5608,d.bmk

Siagian P. Sondang. (2004). Teori Motivasi \& Aplikasinya. Jakarta : Rineka Cipta.

Slameto. (2003). Belajar dan Faktor-faktor yang Mempengaruhinya. Jakarta: Asdi Mahasatya.

Soeharto dkk, (2003). Pengertian Motivasi Belajar Siswa. [ONLINE]

Tersedia:

http://www.sarjanaku.com/2011/05/ motivasi-bela jar-siswa.html

[19Oktober2012]

Sulistiar, Arta dewi (2012). Siswa perlu perhatian dari guru. [ONLINE]
Tersedia :

http://artadewisulistiari.blogspot.co $\mathrm{m} / 2012 / 07 /$ siswa-perlu-perhatiandari-guru.html [24Januari2013]

Sudjana. (2002). Pengertian Motivasi Belajar Siswa. [ONLINE]

Tersedia:

http:/www.sarjanaku.com/2011/05/ motivasi-belajar-siswa.html

[19Oktober2012]

Sudjana. (2002). Metoda Statistika. Bandung: Tarsito.

Sugiyono. (2008). Statistika untuk Penelitian. (Edisi Ketigabelas). Bandung: Alfabeta.

Sugiyono. (2012). Metode Penelitian Pendidikan Pendekatan Kuantitatif, Kualitatif dan R\&D. (Edisi Kelima). Bandung: Alfabeta.

Tim Sosiologi, (2002). Bentuk-bentuk Interaksi Sosial. [ONLINE]

Tersedia: http:/jurnalsdm.blogspot.com/2009/05/interaksi -sosial-definisi-bentuk-ciri.html [20Oktober2012]

Uma Sekaran. (1992). Kerangka Berfikir. [ONLINE]

Tersedia:

http://oemjazz.blogspot.co m/2009/01/kerangka-berpikir.html [20 Oktober2012]

Universitas Pendidikan Indonesia. (2012). Pedoman Penelitian Karya Ilmiah. Bandung : Universitas Pendidikan Indonesia 